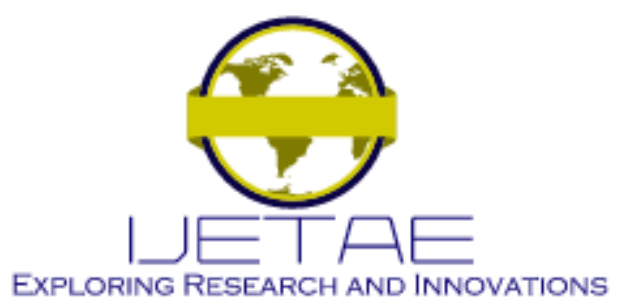

International Journal of Emerging Technology and Advanced Engineering

Website: www.ijetae.com (E-ISSN 2250-2459, Scopus Indexed, ISO 9001:2008 Certified Journal, Volume 11, Issue 10, October 2021)

Manuscript Received: 03 September 2021, Received in Revised form:04 October 2021, Accepted: 13 October 2021

DOI: 10.46338/ijetae1021_08

\title{
Design of a Photovoltaic Pumping System for Irrigation using Solar Energy in the department of Lambayeque-Peru
}

\author{
Eydin Ramos-Cruz ${ }^{1}$, Brian Meneses-Claudio ${ }^{2}$, Alexi Delgado ${ }^{3}$ \\ ${ }^{I}$ Facultad de Ciencias e Ingeniería, Universidad de Ciencias y, Humanidades, Lima, Perú \\ ${ }^{2}$ Image Processing Research Laboratory (INTI-Lab), Universidad de Ciencias y, Humanidades, Lima, Perú \\ ${ }^{3}$ Mining Engineering Section, Pontificia Universidad Católica del Perú, Lima, Perú
}

\begin{abstract}
Due to the large amount of electrical energy necessary for human life and the fact that its origin is nonrenewable, a deterioration of the various ecosystems has been caused, due to the depletion of natural resources. Therefore, it is necessary to find effective solutions that mitigate ecological problems, based on that, this study seeks to implement a photovoltaic pumping system for irrigation using solar energy in the Department of Lambayeque, to take advantage of this natural resource. The methodology implemented is the applied one, with an experimental design. The instrument used for data collection is the registration form. The results showed that effectively the proposed design allows the pumping of a water flow equivalent to $270.4 \mathrm{~m}^{3} /$ day, capturing an average radiation of $6.55 \mathrm{~kW} / \mathrm{m}^{2}$ per day. The use of a charge regulator connected to 4 batteries improved the operation of the photovoltaic pumping system and allows maintaining the durability of the equipment that compose it. It was concluded that the design of the photovoltaic pumping system is effective for the irrigation of crops in Lambayeque.
\end{abstract}

Keywords-- Photovoltaic, solar energy, pumping system, crop irrigation, solar radiation.

\section{INTRODUCTION}

In South America, the countries with the highest electricity generation are Brazil (568 billion $\mathrm{kWh}$ ), followed by Argentina (132 billion kWh) and Venezuela (109 billion $\mathrm{kWh}$ ) ; having Guyana with the lowest production of just one billion $\mathrm{kWh}$, while in the Falkland Islands electricity is not generated, on the contrary, it is an importer of all that it consumes [1].

In Peru, the generation of electricity during the month of March 2021 was $4968 \mathrm{GWh}$, showing an increase of $15.3 \%$, in proportion to the same month in the previous year. Of all this energy produced, $96 \%$ was by generators in the electricity market and only $4 \%$ by units of industrial companies for its use.
Generation is divided into: hydroelectric production, which had an increase of $16 \%$, solar and wind production was $64 \mathrm{GWh}$ and $136 \mathrm{GWh}$, which represents $4 \%$ of the total energy generated nationwide in 2020 [2].

Due to the high amount of electrical energy produced and its non-renewable origin, in recent times there has been a deterioration of the ecosystem and depletion of natural resources generating serious consequences such as environmental pollution. Hence, the importance of seeking effective solutions which to mitigate the effects of climate change produced by heavy pollution [3].

Diversifying the obtaining of electrical energy from other means that do not adversely affect the health of living beings and the environment in general, it is a enough reason to have the prevailing need to detect new methods applicable to the generation of electrical energy from sunlight using photovoltaic cells to be used in such necessary and routine activities as crop irrigation [4].

The photovoltaic water pumping system is responsible for converting solar energy into electrical energy through photovoltaic panels, with the purpose of being manipulated to operate electric pumps. This energy produced by the panels is used to supply direct current motors with energy or to transform it into alternating current by the inverter [5].

The possibility of that energy being stored in batteries depends on the installation. This would reduce costs, increase the benefit to citizens and solve the energy problem by carrying out the irrigation of crops in the country with sustainable and environmentally friendly energy, thinking about the future generations [4]. Due to this and all the above, the need to implement a photovoltaic pumping system for irrigation using solar energy emerges in the Department of Lambayeque. 


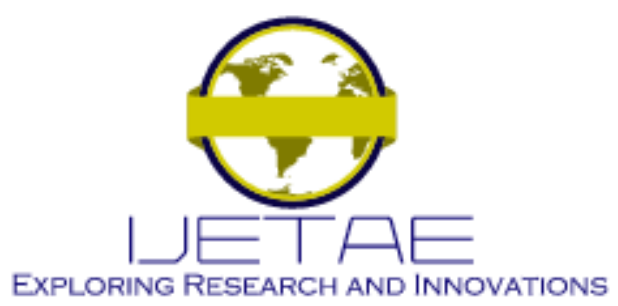

International Journal of Emerging Technology and Advanced Engineering

Website: www.ijetae.com (E-ISSN 2250-2459, Scopus Indexed, ISO 9001:2008 Certified Journal, Volume 11, Issue 10, October 2021)

In [4], a pumping system with photovoltaic panels is dimensioned to be used in crop irrigation, since generating solar energy has become the answer to the increase in energy demand in agriculture, replacing fossil fuel. It is important to highlight the need to have the solar resource available and the energy and water demand existing in the agricultural area, which also implied a low cost of this system compared to that generated by a gasoline power plant.

In [6], the elaboration of 247 solar panels of 260 watts, two hundred and sixteen 24-volt batteries made up of photovoltaic cells, modeled with a neural network, obtaining an energy capture gain was $23.9 \%$ exposing it daily in a mobile panel, executing the environmental impact analysis, it was carried out through the CRI methodology, verifying that it does not generate significant environmental impacts.

In [7], ten archetypes of photovoltaic cells based on titanium dioxide were elaborated where the type and time of exposure to the dye varied, the prototype for the elaboration of effective photovoltaic cells was measured, compared and identified, obtaining as a result that the highest efficiency is found in the exposure to the aguaymanto pigment with a value of $2.33 \mathrm{E}-6 \%$ in 2 hours. It was concluded that this pigment favors obtaining solar energy efficiently and in less time.

This research work shows as the main objective the simulation of a photovoltaic pumping system for irrigation using solar energy in the Department of Lambayeque. In this way, it is pursued not only the protection of the environment and the use of natural resources, but also the reduction of costs due to the long routines of irrigation of crops.

Although it is true that the installation of photovoltaic cells and systems is usually highly expensive for many companies and populations, it is necessary to adapt these types of electricity generation systems with renewable resources so that they can be available to farmers [7], so, they could supply water to their crops, located in remote locations with this precious resource, thus also allowing the farmer to invest in this type of systems for the supply of their own energy, thereby reducing the consumption of electricity generated in the usual way [4].

It should be understood that the solar cell or photovoltaic cell is an instrument made through very thin sheets of square-shaped semiconductor materials whose importance is to convert the photons radiated by sunlight into electricity [8].
While the generation of electrical energy is the measure obtained through the conversion phenomenon, this being the correlation between light energy and the electrical energy that can be generated with it [9].

This study is structured as follows: In section II, the methodology applied in the research work with its respective analyzes is presented. In section III, the results of the research work with the development of the cells are presented, specifying the relevant data, and structuring an analysis of each information obtained. In section IV, the discussion of the results achieved is presented, comparing them with authors who have carried out similar studies. Finally, in section $\mathrm{V}$, the conclusions of the research work are presented, with their respective recommendations.

\section{Methodology}

In this part, the typology of the investigation as applied is developed, since it was intended to determine the efficiency of a photovoltaic cell in the generation of electrical energy to use it in the irrigation of crops.

The study design is experimental, because through the creation and manipulation of photovoltaic cells, the efficiency of these cells in generating electricity is measured. Likewise, this research with experimental design according to the measure of manipulation of the variables is positioned as a pre-experimental design, since the level of manipulation that was given to the photovoltaic cell is minimal through the case study with a single measurement [10].

Due to the nature of the study, the population and sample are the same, developing a photovoltaic irrigation system with twenty (20) photovoltaic panels, made with a base of titanium dioxide and borax, $135 \mathrm{WP}, 12 \mathrm{~V}$, subjected to an exposure time to solar radiation equivalent to 6 hours, between 10:00 am and 4:00 pm, connected to hydraulic pumps, in turn connected to water storage tanks. For a period of 4 business days, preferably in the winter season at the end of April of this year; located in the Department of Lambayeque as a strategic point regarding cultivation.

For the selection of the sample to be used in the research, the non-probability sampling technique was used at convenience, since the amount of population available for the collection of information is less than 30 and because absolutely all the population units comply with the characteristics of the study [10]. 


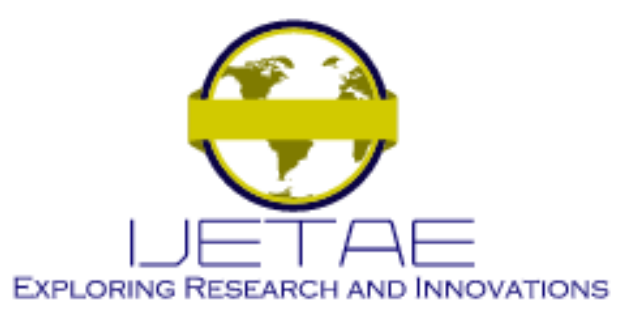

International Journal of Emerging Technology and Advanced Engineering

Website: www.ijetae.com (E-ISSN 2250-2459, Scopus Indexed, ISO 9001:2008 Certified Journal, Volume 11, Issue 10, October 2021)

Observation was used for the development of the study, since it allows to collect data and information directly concerning the process of creating prototypes of photovoltaic cells based on titanium dioxide and borax and, the efficiency measurements that the cells have in the generation of electrical energy.

The type of instrument used was an information record sheet, made up of a total of three sheets: record sheet of daily solar radiation analysis for monthly average, record sheet of prototype development of the photovoltaic irrigation pumping system and sheet of data collection.

The following materials were used: 8 photovoltaic panels made with a base of titanium dioxide and borax, hydraulic pumps, pipes, storage tanks, inverter, and solar regulator. The cultivation land has the following characteristics: semitropical, with high atmospheric humidity and little rainfall and great potential for the emission of solar radiation.

The photovoltaic pumping system presents a series of processes for its operation, these processes are verified in a flow diagram shown in Figure 1.

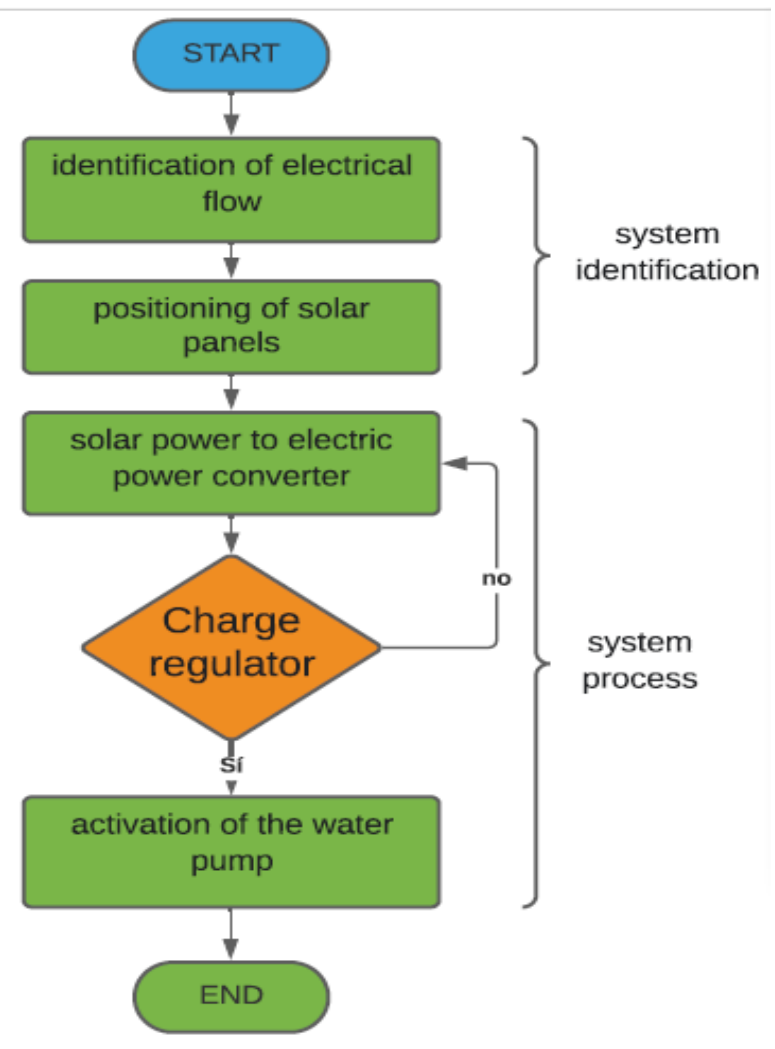

Fig 1 Installation flow diagram of the Irrigation System with photovoltaic cells

\section{A. System Identification}

To identify the system, it was required to carry out a series of calculations that allow the identification of the system components. Therefore, the total area to irrigate will be 2 hectares that require $270.4 \mathrm{~m}^{3} /$ day, located in Lambayeque, at the coordinates $6^{\circ} 43^{\prime} 9.59^{\prime}$ 'S of latitude and $79^{\circ} 54^{\prime} 30.02$ ' $\mathrm{W}$ of longitude. The estimate of the daily solar radiation level will be taken from the meteorological data.

There are monocrystalline photovoltaic panels composed of 36 cells, $100 \mathrm{Wp}, 12 \mathrm{~V}$, with a yield of $12.5 \%$ efficiency (selected for their availability and cost). The number of panels was determined according to the formula Np-t $=\geq$ $\mathrm{Pg} / \mathrm{Pmax}$. Where $\mathrm{Np}-\mathrm{t}$ total number of photovoltaic panels, Pmax p maximum power of the pump, giving a total of 8 panels needed. To maintain the useful life of the panels, shadows were avoided on and between them, guaranteeing that they were free for at least 8 hours a day [11].

TABLE 1

Photovoltaic Panel Specifications

\begin{tabular}{|c|c|}
\hline $\begin{array}{c}\text { Number of cells } \\
\text { Maximum power } \\
(\mathrm{Wp})\end{array}$ & $100 \mathrm{~W}$ \\
\hline $\begin{array}{c}\text { Power tolerance } \\
\pm 3 \%\end{array}$ \\
\hline $\begin{array}{c}\text { Open circuit voltage } \\
\text { Maximum Power } \\
\text { Voltage (Vm) }\end{array}$ & $18.79 \mathrm{~A}$ \\
\hline $\begin{array}{c}\text { Maximum power } \\
\text { current (Im) }\end{array}$ & $5.46 \mathrm{~A}$ \\
\hline $\begin{array}{c}\text { Maximum Series } \\
\text { Fuse }\end{array}$ & $10 \mathrm{~A}$ \\
\hline Number of diodes & 2 \\
\hline Module efficiency & $14.6 \%$ \\
\hline Certificate & $\begin{array}{c}\text { ISO9001, } \\
\text { ISO14001, }\end{array}$ \\
\hline
\end{tabular}

Likewise, the electric flux necessary for the operation of the pumping system is identified through the equation: $N_{p-t}$ $\geq P_{g} / P_{\operatorname{maxp}}$. Where $\mathrm{Np}-\mathrm{t}$ total number of photovoltaic panels, Pmax p maximum power of the hydraulic pump. The orientation of the panels will be made by calculating through the equation: $\beta o p t=3,7+0,69|\phi|$. Where: $\beta o p t$ optimal tilt angle (degrees), and $|\phi|$ latitude of unsigned location (grades) [12]. 


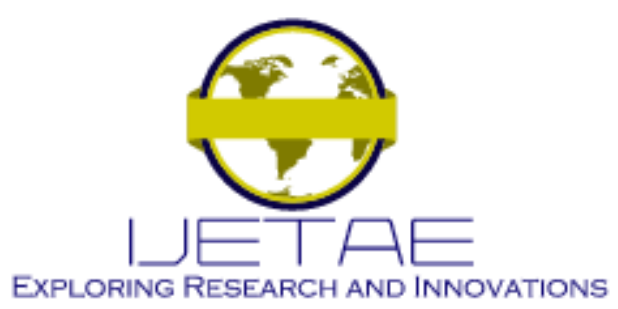

International Journal of Emerging Technology and Advanced Engineering Website: www.ijetae.com (E-ISSN 2250-2459, Scopus Indexed, ISO 9001:2008 Certified Journal, Volume 11, Issue 10, October 2021)

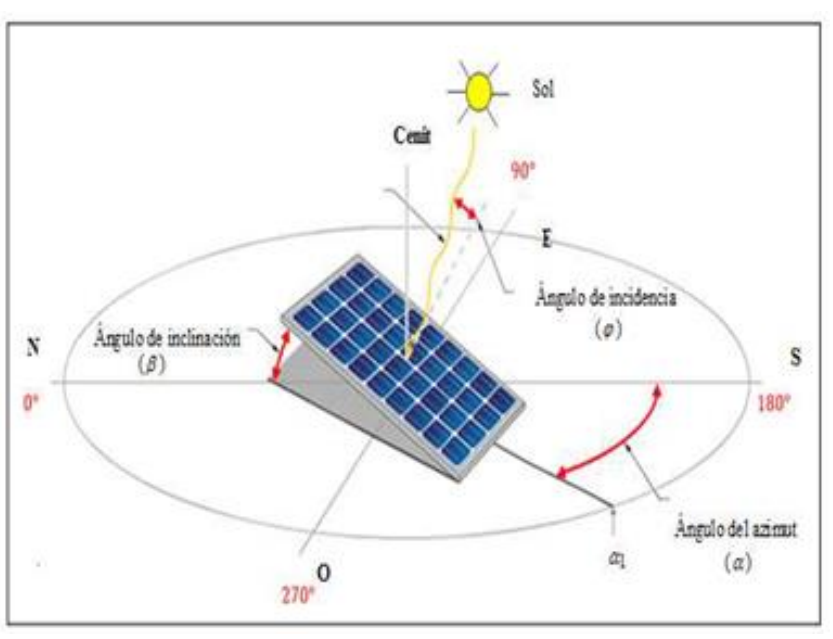

Fig 2 Panel orientation

\section{B. System Process}

In this stage, to identify the solar to electric energy converter, it is necessary to establish the energy demand (through the equation $\mathrm{h} \mathrm{TE}=(\mathrm{hD}+\mathrm{hST}+\mathrm{hab}) \times 1.1)$ and the existing need for water (a through the equation $\mathrm{N}^{\circ}$ Plants $=10000 \times \mathrm{H} / \mathrm{D} \times \mathrm{L})$. Where: $\mathrm{H}$ number of hectares, $\mathrm{D}$ distance between plants $(\mathrm{m})$, and $\mathrm{L}$ distance between lines, in addition to $\mathrm{hD}$ height of the deposit, hST static height, hDT dynamic height, and hab is the abatement [4].

Considering an average yield of $40 \%$ of alternating current, it is necessary to calculate the electrical energy demanded for the loggia pumping the flow, through the equation $E p \max d=E n / \eta m b$. Where: Epmax d electric energy of maximum power (kWh / day), Eh daily hydraulic energy ( $\mathrm{kWh} / \mathrm{day})$, and $\mathrm{nmb}$ mean performance of the hydraulic pump system [7].

Later, to establish the power of the energy converter, the equation $P g=F S \times E p \max d / E n \times H S P \times K_{T}$. Where: Pg generator power $(\mathrm{kW}), \mathrm{FS}$ installation safety factor, Epmax $\mathrm{d}$ maximum power electrical energy ( $\mathrm{kWh} / \mathrm{day}$ ), HSP hours + solar, and KT installation losses [13].

The charge regulator was determined by observing the amperage indicated on the solar panel and multiplying it by the number of panels that were installed for the pumping system [14], which in this case were 8. Therefore, the regulator reaches a maximum of 50 , which can be covered with a single charge controller.

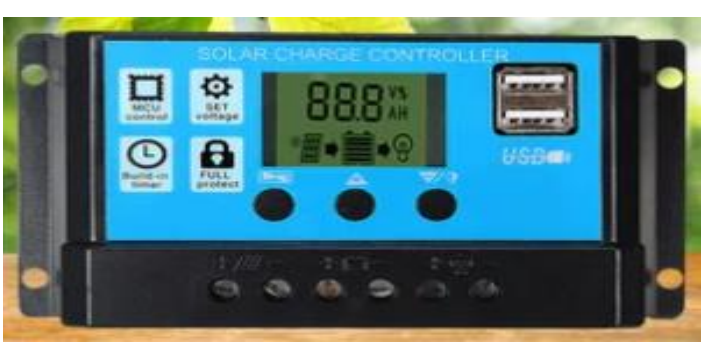

Fig 3Charge regulator 50 A 12 / 24V Basic

The water pump, in this case a submersible electric pump, must have the capacity to withstand a peak flow from the generator power. Once, these calculations have been determined, each of the components of the photovoltaic pumping system is connected, in order to carry out the preexperiment, ensuring the solar inverter and the solar regulator to the hydraulic pump [12].

The batteries will be 4 , with them the energy directed to the pump will be controlled to maintain a constant voltage to maintain the durability of the equipment.

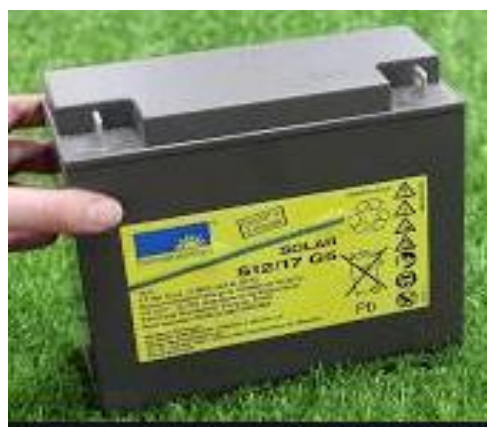

Fig 4 Gel battery 24v 130

Having explained this, the demand for water for irrigation was met using the energy generated by panels through an isolated photovoltaic system with regulator and inverter, which is mandatory when a load is required to be fed in alternating current [15] 


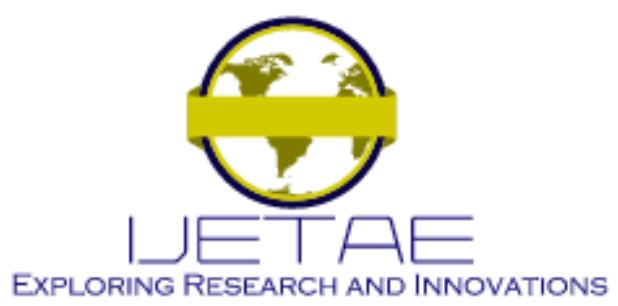

International Journal of Emerging Technology and Advanced Engineering

Website: www.ijetae.com (E-ISSN 2250-2459, Scopus Indexed, ISO 9001:2008 Certified Journal, Volume 11, Issue 10, October 2021)

TABLE 2

Characteristics OF THE EQUiPMENT USED

\begin{tabular}{|c|c|c|c|c|}
\hline Equipment & Quantity & Name & Amperage & Voltage \\
\hline Solar panel & 8 & $\begin{array}{c}\text { Monocrystal } \\
\text { inox 100Wp }\end{array}$ & $5.95 \mathrm{~A}$ & $12 \mathrm{VDC}$ \\
\hline $\begin{array}{c}\text { Power } \\
\text { converter }\end{array}$ & 1 & $\begin{array}{c}\text { Inverter } \\
4000 \mathrm{~W}\end{array}$ & $4000 \mathrm{w}$ & $\begin{array}{c}24 \mathrm{VDC} / 230 \\
\mathrm{VAC}\end{array}$ \\
\hline $\begin{array}{c}\text { Charge } \\
\text { regulator }\end{array}$ & 1 & $\begin{array}{c}\text { Charge } \\
\text { controller } \\
50 \mathrm{~A} \\
12 / 24 \mathrm{~V} \\
\text { Basic }\end{array}$ & 50 & $24 \mathrm{VDC}$ \\
\hline Batteries & 4 & $\begin{array}{c}\text { Battery of } \\
\text { Gel } 24 \mathrm{v} 130 \\
\text { Ahsonnensc } \\
\text { Hein s12- } \\
130\end{array}$ & $130 \mathrm{~A}$ & $24 \mathrm{VDC}$ \\
\hline $\begin{array}{c}\text { Submersible } \\
\text { electric pump }\end{array}$ & 1 & $\begin{array}{c}\text { Pedrolle } \\
\text { 4Block }\end{array}$ & 8A & $220 \mathrm{VAC}$ \\
\hline
\end{tabular}

\section{RESULTS}

For the average daily energy of solar radiation, the information obtained in accordance with the Lambayeque national system was taken, and the radiation levels obtained through the RETScreen Expert program are:

TABLE 3

\section{RADIATION ENERGY SPECIFICATIONS}

\begin{tabular}{|c|c|}
\hline Months & Irradiation \\
\hline January & $6.62 \mathrm{kw} / \mathrm{m}^{2} *$ day \\
\hline February & $6.59 \mathrm{kw} / \mathrm{m}^{2} *$ day \\
\hline March & $6.66 \mathrm{kw} / \mathrm{m}^{2} *$ day \\
\hline April & $6.42 \mathrm{kw} / \mathrm{m}^{2}$ day \\
\hline Average & $6.55 \mathrm{kw} / \mathrm{m}^{2} *$ day \\
\hline
\end{tabular}

Therefore, an average of $6.55 \mathrm{kw} / \mathrm{m}^{2} *$ day irradiation day is obtained. CA equipment was used. Subsequently, the installation's voltage consumption is determined daily, with Ereal of 2,825.51 Wh/day.

TABLE 4

VOLTAGE CONSUMPTION SPECIFICATIONS

\begin{tabular}{|c|c|c|c|}
\hline Months & Irradiation & $\begin{array}{c}\text { Theoretical } \\
\text { consumption } \\
\text { Wh/día }\end{array}$ & Ymax \\
\hline January & $6.62 \mathrm{kw} / \mathrm{m}^{2} *$ day & $\begin{array}{c}2,825.51 \\
\text { Wh/day }\end{array}$ & 426.81 \\
\hline February & $6.59 \mathrm{kw} / \mathrm{m}^{2} *$ day & $\begin{array}{c}2,825.51 \\
\text { Wh/day }\end{array}$ & 428.76 \\
\hline March & $6.66 \mathrm{kw} / \mathrm{m}^{2} *$ day & $\begin{array}{c}2,825.51 \\
\text { Wh/day }\end{array}$ & 424.25 \\
\hline April & $6.42 \mathrm{kw} / \mathrm{m}^{2}$ day & $\begin{array}{c}2,825.51 \\
\text { Wh/day }\end{array}$ & 440.11 \\
\hline Average & $6.55 \mathrm{kw} / \mathrm{m}^{2}$ day & $\begin{array}{c}2,825.51 \\
\text { Wh/day }\end{array}$ & 429.98 \\
\hline
\end{tabular}

When choosing the pumping equipment and the parts that compose it in the design, it is sought to use renewable energy sources. According to the established calculations, the daily power is estimated at $2,825.51 \mathrm{~W} /$ day, using the 8 solar panels, which makes it necessary to store energy in 4 batteries that will feed the submersible pump, which will pump the water into a tank. Elevated with a capacity of 274 $\mathrm{m}^{3}$, for the proper control of irrigation from the deck.

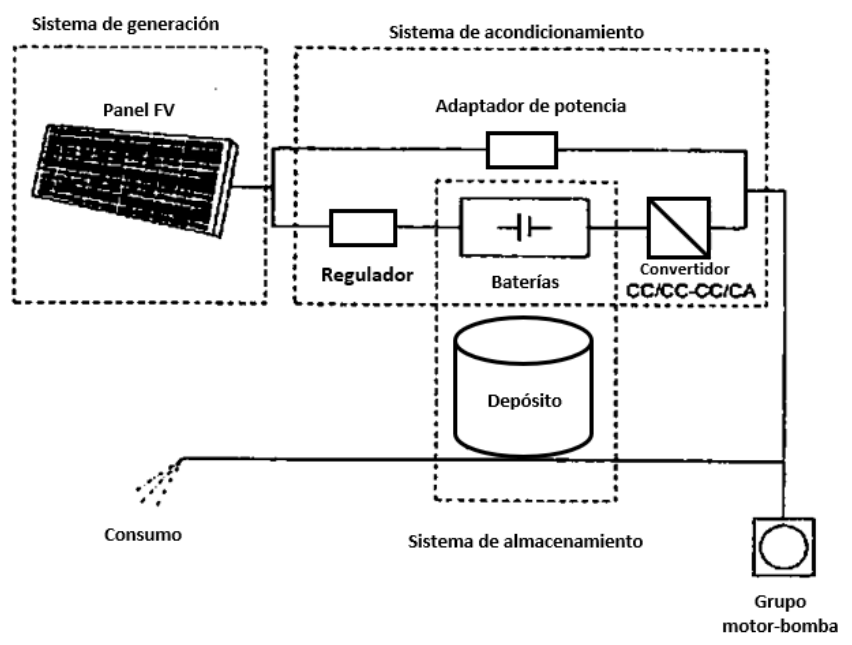

Fig 5 Photovoltaic pumping system coupled with batteries

The flow needed to irrigate the 2 hectares of crops is 270 $\mathrm{m}^{3}$ per day, and the most convenient type of irrigation will be drip irrigation. Once this has been determined, the installation of the system is proceeded by placing the photovoltaic panels around the plot to be cultivated, following a linear methodology, for the placement of both the electrical equipment and the rain system, in such a way that it gives the best performance according to with what is specified and calculated.

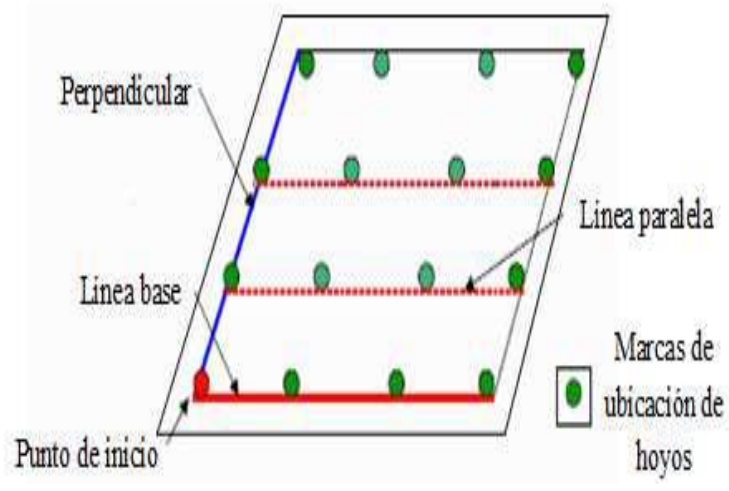

Fig 6 Marking lines 


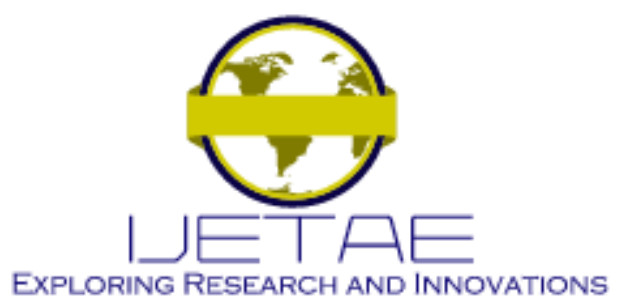

International Journal of Emerging Technology and Advanced Engineering

Website: www.ijetae.com (E-ISSN 2250-2459, Scopus Indexed, ISO 9001:2008 Certified Journal, Volume 11, Issue 10, October 2021)

Then, they are connected to the charge regulator and the charge inverter, to later connect the pipe system that would transport the water to the storage tanks and to the cultivation.

In this way, this photovoltaic pumping system receives solar radiation, which is transformed into electrical energy by the charge inverter. The charge controller sends this energy to the batteries which are charged, to supply power to the water pump when required. These batteries are necessary because they maintain a constant operating voltage to the pump motor.

The installed regulator controlled the charge to the batteries so that they stored without overcharging, preventing overcharging until the batteries reached their charge capacity limit. Thus, each part of the different components installed and connected in the manner shown in figure 7 , the photovoltaic pumping system for irrigation using solar energy is implemented in the district of Lambayeque.

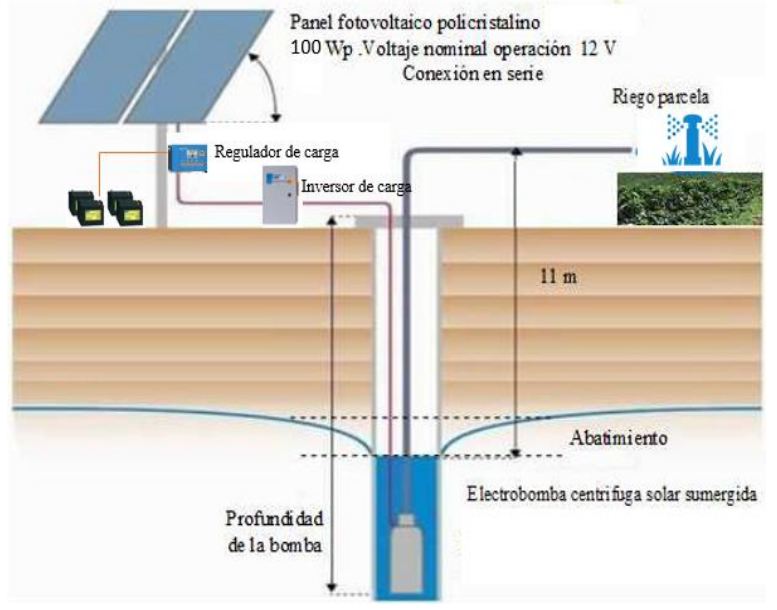

Fig 7 Photovoltaic pumping system for irrigation

Total budget of electronic equipment for the implementation of the photovoltaic pumping system for irrigation. Table VI.
TABLE 5

COSTS OF ELECTRONIC EQUIPMENT

\begin{tabular}{|c|c|c|}
\hline Electronic Devices & Quantity & Prices (PEN) \\
\hline Solar panel & 8 & $2,926.48$ \\
\hline Power converter & 1 & 9223.69 \\
\hline Charge regulator & 1 & 1106.81 \\
\hline Batteries & 4 & $9,962.75$ \\
\hline $\begin{array}{c}\text { Submersible electric } \\
\text { pump }\end{array}$ & 1 & $2,731.66$ \\
\hline Total S/. 25,951.39 \\
\hline
\end{tabular}

In Peru there are several companies that provide the service of installation of photovoltaic systems using renewable energies, some of the companies that have more than 25 years of experience and that provide a quality service are.

Q-ENERGY has highly trained personnel with proven experience implementing projects in all regions of Peru.

WAIRA, energy and sustainable mobility, this company has more than 25 years providing service nationwide.

\section{DISCUSSION}

The general objective of this research work was to implement a photovoltaic pumping system for irrigation using solar energy in the Department of Lambayeque, a design that was carried out for an area of 2 hectares in Lambayeque, which required $270.4 \mathrm{~m}^{3} /$ day of water for irrigation. With the analysis and study of various authors, the experiment was located within the selected area.

8 monocrystalline photovoltaic panels of 12VDC 100W were installed connected to each other in parallel, 1 power converter, 1 charge regulator of $50 \mathrm{~A}, 4$ batteries 124 of $24 \mathrm{~V}$, a submersible electric pump, among others. Through the application of various formulas, exact calculations were made to accurately determine the requirements of this project, thus achieving the proposed objective. 


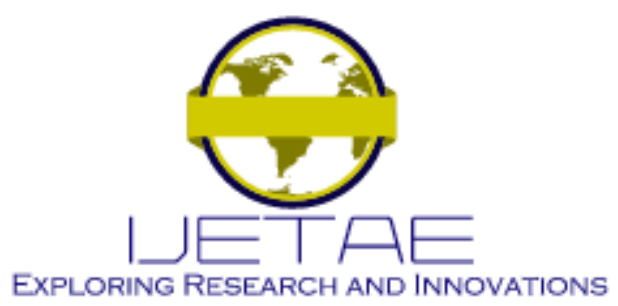

International Journal of Emerging Technology and Advanced Engineering

Website: www.ijetae.com (E-ISSN 2250-2459, Scopus Indexed, ISO 9001:2008 Certified Journal, Volume 11, Issue 10, October 2021)

This research work agrees with what was stated by [4] who, with a pumping system with photovoltaic panels in crop irrigation, seeks to generate solar energy in view of the energy demand in agriculture. In addition [6] and [7] proposed the manufacture of more effective photovoltaic panels to not only capture solar radiation, but also to do so in the shortest possible time.

In addition, the method used in this study agrees with that stated by [4] because it is necessary not only to obtain the necessary energy to pump the water required by the crop, but also to pump water to the storage tank. Although, we disagree with this author, the fact that it is also required to store electrical energy in batteries, if solar radiation decreases on a day with bad weather, or any other inconvenience that may arise.

It agrees with [5] who points out that not only should the photovoltaic pumping system be implemented, shadows that interrupt the flow of radiation and energy should also be avoided, as this can damage the installed equipment. That is the importance of locating the photovoltaic panels, always avoiding these inconveniences that can take away the useful life of the equipment.

It is necessary to warn that the system must be installed in such a way that it starts and stops automatically according to demand, because ignoring implements such as batteries could lead to a short useful life of this equipment. It must also be considered that complying with this design allows water to be pumped when solar radiation is available, although it can be supplied by using the energy stored in the batteries.

\section{CONCLUSIONS}

It was concluded that the design of the photovoltaic pumping system for irrigation of a Lambayeque crop is effective and durable, since quality equipment was selected, and the system was designed in such a way that they do not suffer deterioration due to a malfunction.

It was concluded that the photovoltaic pumping system will use solar energy as an energy source, which makes it viable to work in larger areas of cultivation. This also because the processed electrical energy is stored in the batteries thanks to the charge regulator.

The need to store water in the reservoir tank was concluded to prevent any eventuality with the volume of liquid required for cultivation.
In addition, electrical energy is also being stored in the batteries, since these correct the voltage variety and, therefore, prevent damage to the equipment that makes up the designed system.

It was concluded that the implementation of this design of a photovoltaic pumping system for irrigation can be used in corn, onion, papaya, grape, and asparagus crops, among others.

Cleaning of the solar panels is recommended once a month, in addition to checking the condition and proper functioning of all the equipment that makes up the photovoltaic pumping system, to maintain and improve the efficiency of the equipment.

\section{REFERENCES}

[1] IndexMundi, "IndexMundi," 2019.

[2] MINEM, "Preliminary figures for the electricity sector," 2021.

[3] clean as a right and guarantee, related to the right to a healthy environment, "Rev. la Univ. Católica Colomb., Vol. 2018, no. 1, pp. $1-55,2018$.

[4] J. Vera, R. Herrera, "Dimensioning of a Solar Pumping System for Agricultural Irrigation in the Roblepampa Town Center, Utcubamba - Amazonas," National University of Jaén, 2020.

[5] photovoltaic for high-efficiency power conversion., 2nd Ed. Massachusetts, USA, 2014.

[6] S. L. Bellota, "Process of generating electrical energy from solar energy for industrial use: Non-metallic mineral drying plant," Universidad Nacional de San Agustín de Arequipa, 2018.

[7] P. R. Silva, "Efficiency of nanostructured photovoltaic cells based on titanium dioxide, sensitized with native Peruvian pigments in Chaclacayo - 2018," Universidad Cesar Vallejo, 2018.

[8] A. Fagual and W. Bernal, "organic solar cells," Rev. Ciencia, Innovación y Tecnol., Vol. I, no. 2015, pp. 71-81, 2015.

[9] V. M. Moro, "Photovoltaic solar installations," Paraninfo, vol. 2018, no. 2, pp. 32-42, 2018.

[10] M. Borja, methodology of Scientific Research for Engineers, 1st. Chiclayo, 2012.

[11] B. Orozco, "Investigation of the migration from conventional energy to photovoltaic energy at the main headquarters of Aguas de Manizales S.A. Bogotá, Colombia, "National Open and Distance University, 2019.

[12] O. Perpiñan, A. Colmenar, and M. Castro, Design of photovoltaic cells, 2a. Madrid, Spain, 2012.

[13] R. Yarlaque and E. Flores, "Design of a photovoltaic pumping system for drip irrigation in the San José farm - Caserío La Colorada - Morrope District - Lambayeque Department," Universidad Nacional Pedro Ruíz gallo.

[14] C. H. Yong, "Over 16\% efficiency organic photovoltaic cells enable by chlorinated acceptor with increased open-circuit voltages," Nat. Comun., Vol. 1, no. 2019, pp. 1-8, 2019.

[15] J. Méndez, Photovoltaic solar energy, 4th Ed. Mexico City, 2017. 